so successful. The crisis which threatened the massive development gains in East Asia and the performance of the world economy showed that such systems were unsustainable and I am pleased to say the arguments of the cynics are now completely overtaken.

But for me, worst of all, corruption hurts the poor. The eloquence of their anger at petty corruption worldwide shows there is no such thing as a culture of corruption.

And if we look at the poorest countries and continents in the world, we find terrible poverty side by side with great riches, with corruption in between. And we see development delayed and poverty linger because massive resources are wasted and misused for corrupt purposes. We can and must do better.
The Rt Hon Clare Short MP

Secretary of State for International Development

\title{
Collective rights: the case of indigenous peoples
}

\author{
by Alexandra Xanthaki
}

Pending agreement on a UN Declaration on the Rights of Indigenous Peoples, Alexandra Xanthaki examines the political theories and research supporting the need for recognition of collective identities and rights, which she claims have hitherto been overshadowed by the focus on rights of the individual.

I ndigenous expectations for a 'Declaration on the Rights of Indigenous Peoples' that would include a wide range of collective rights have sparked lively debates between states, indigenous representatives and experts in the United Nations Working Group on Indigenous Peoples. Indigenous representatives insist that the individualistic view of the world is totally alien to the indigenous ideas of the world, their traditions, their past and their present. An exclusive emphasis on individual rights has not and cannot give effective guarantees for indigenous peoples, who require the simultaneous protection as collectivities in order to survive and flourish as distinct peoples and cultures.

Collective rights emphasise the value of protecting indigenous cultures and existence per se and reject assimilation and integration as valid modes of relating to indigenous peoples. Indigenous peoples have stated:

'The concept of indigenous peoples' collective rights is of paramount importance. It is the establishment of rights of peoples as groups, and not merely the recognition of individual rights, which is one of the most important purposes of this Declaration. Without this, the Declaration cannot adequately protect our most basic interests. This must not be compromised.' (emphasis added)

(UN Sub-Commission, Indigenous Peoples Preparatory Meeting: Comments on the First Revised Text of the Draft Declaration on Rights of Indigenous Peoples, July 1989.)
In contrast, some states use liberal theory in order to reject the notion of collective rights. The French delegate, for example, stated in the 1996 Working Group on Indigenous Peoples that collective rights did not exist in international human rights law, and therefore his government had reservations with regard to those articles that aimed to establish collective rights. In similar fashion, the US explained its rejection of indigenous collective rights (in its delegation's comments on s. 1 of the Draft Declaration in the 1995 Working Group) on the basis that:

'International instruments generally speak of individual not collective rights. ... Making clear that the rights guaranteed are those of individuals prevents governments or groups of (sic) violating or interfering with them in the name of the greater good of a group or a state ... In certain cases, it is entirely appropriate or necessary to refer to indigenous communities or groups, in order to reinforce their individual civil and political rights on the basis of full equality and nondiscrimination. But characterising a right as belonging to a community, or collective, rather than an individual, can be and often is construed to limit the exercise of that right (since only a group can invoke it), and thus may open the door to the denial of the right to the individual. This approach is consistent with the general view of the US, as developed by its domestic experience, that the rights of all people are best assured when the rights of each person are effectively protected.'

The traditional approach of liberal rights theory recognises only two categories of rights holders: the individual and the 
society. In their historical evolution, human rights have been perceived as the rights of individuals against state power. Opponents of collective rights base their arguments on cosmopolitanism, a theory which advocates for autonomous individuals who are free from their cultural tradition and can therefore make autonomous decisions, in contrast to the communitarian theory according to which the self has attachments to the culture he/she has grown up in. Liberals argue that the establishment of collective rights will reflect a totalitarian vision of the society and will raise tribalist or nationalistic attitudes.

The extensive philosophising on the need for cultural membership and collective rights is generally perceived by international lawyers as very engaging and very relevant to legal debates on claims for collective rights; yet, sometimes it appears to be lagging behind new developments in international law. If international law is defined as the system of rules and principles that govern international relations (Martin Dixon, Textbook on International Law, 3rd edn, London: Blackstone Press Ltd, 1996, 2 ), its normative direction on the issue cannot be ignored.

In this article, I will focus on three elements which form the direction international law has taken in the debate on cultural membership and collective rights:

- the perception of groups as concentric circles;

- the idea of togetherness in difference; and

- the model of critical pluralism.

\section{GROUPS AS CONCENTRIC CIRCLES}

The liberal emphasis on the dichotomy between the individual and the state ignores the existence of any intermediate groups. The rejection of collective rights derives from a notion of 'monotheism of the state', namely unlimited sovereignty of the state and the view that the state should be the only source of authority in each political system. However, this model appears to be inconsistent with the existing norms of international law as well as the international political realities. In the post-national state, although sharing the state's national identity, citizens have in most cases other loyalties as well. These loyalties may lie in groups smaller than the state, such as families, local communities, ethnic, religious and cultural groups, as well as groups bigger than the state, such as regional organisations (e.g. the European Union) or even the international society. All these groups represent a series of multiple loyalties that the individual has and consequently incorporate various cultures that influence the individual. For example, a Sami who lives in Finland has been exposed to the specific culture of his family, the culture of his village (which sometimes has a different linguistic dialect), the Sami culture, the Finnish culture as well as the European culture.

International law is in the process of recognising various subnational groups other than the state. International norms are in the process of expanding the number of entities that enjoy legal personality - if only for some purposes. Currently, non-state entities such as inter-governmental organisations, regional organisations, non-self-governing territories, liberation movements and insurgent communities, non-governmental organisations, corporations and autonomous local administrations can act to some extent as agents in the international arena (see Martin Dixon, op cit, 109-110, and Ian Brownlie, Principles of Public International Law, 4th edn, Oxford: Clarendon Press, 1992, 58-70).

International law goes even further and recognises the importance of groups in the life of the individual. The 1989 UNESCO Recommendation on the Safeguarding of Traditional Culture and Folklore protects the culture of sub-national groups. Also, the Convention on the Rights of the Child states that education must develop respect for the child's 'own cultural identity, language and values' as well as for 'the national values of the country in which the child is living'. Although the human rights system gives the central role to the individual, protection is also given to the person as a member of groups, such as the family, ethnic, national, religious and linguistic groups and nations (peoples). Even though most of these provisions establish individual rights or individual rights in collective capacity, their spirit recognises the importance of groups for the individual and prescribes that these groups should be protected.

By protecting the various sub-groups that surround the individual, it appears that international law perceives these groups as forming concentric circles around the person. Apart from having his/her own attributes and choices as an independent agent, the person is also influenced by his/her immediate group (such as the family), peer group (such as the local group), ethnic, religious and cultural group, his/her nation (peoples), state, continent/region and, finally, loosely by the main culture we all share as citizens of a common world. The closer the circle to the person, the more influence it has on him/her. In order to protect the individual, all the various 'circles' - loyalties - around him/her need to be protected. Thus, international law includes a different set of protection for the individual (by establishing individual rights), but also his/her family, ethnic, cultural or religious group, the society he/she lives in, and finally the culture of his/her continent and the culture of the world itself (by establishing collective rights) (see Ronald Garet, 'Communality and Existence: The Rights of Groups', 56 (1993) South California Law Review, 1001-1050). As Waldron argues (in Jeremy Waldron, 'Minority Cultures and the Cosmopolitan Alternative' 25 (1995) University of Michigan Journal of Law Reform, 751-793, as reprinted in Will Kymlicka (ed), The Rights of Minority Cultures, Oxford University Press, 1995, 93-119, 103):

'Just as the allegedly self-made individual needs to be brought to a proper awareness of [his/]her dependence on social, communal and cultural structures, so too in the modern world particular cultures and national communities have an obligation to recognise their dependence on the wider social, political, international and civilisational structures that sustain them.'

The illustration of the self and its various cultural memberships as concentric circles seems to represent an accurate and viable perception of the link between the person, non-state groups and society. It follows the communitarian approach on the importance of cultural frameworks, but it is liberated from the trap of 'one culture'. It recognises that more than one culture can play a valuable role in the individual's choices; it accepts that in the post-national world individuals can have several loyalties without them being opposing or dangerous to national unity and it indicates the interplay that exists among cultures. 


\section{Personalism}

This approach has also been upheld by personalism. Personalists consider the individualistic tradition and the communitarian approach to be complementary rather than contrasting. According to the Encyclopaedia of Philosophy, personalism is defined as:

'[a] philosophical perspective or system for which person is the ontological ultimate and for which personality is thus the fundamental explanatory principle.'

Personalists regard the 'person' as an essential part of the community, as distinct from the 'individual', who is regarded as an isolated entity (Virginia A Leary, "Postliberal strands in Western Human Rights Theory" in Abdullah Ahmed An-Nam (ed), Human Rights in Cross-Cultural Perspectives. A Quest for Consensus, Philadelphia: University of Pennsylvania Press, 1992, 105-132, 108). The term 'person' or 'personality' implies relationships with others in the community and a corresponding link with the community and the relations between persons and society. Personalists believe that a person is inseparable from the context of the world and of others. The person lives in community with others and not as an isolated individual; thus, personalists support the establishment of community rights, particularly for communities smaller than the state. However, personalists do not ignore the negative consequences of group membership; thus, rights exist to counteract the tyranny of the state as well as the tyranny of groups and they can be claimed against the state as well as groups. The personalist perspective of rights offers a western conception of human rights which is not constrained to individual rights.

The model of personalism appears to be a viable model for indigenous peoples and the recognition of their rights. The Indian Crees, for example, share the culture of their reservation, the culture of the overlapping American Indian community and they also share characteristics of the Canadian culture; they also feel part of the North American culture as well as members of the international community. Their lives and choices represent a mixture of characteristics of these cultures and they want to preserve and protect all of these characteristics. Their collective rights will protect them from the states and the other groups; their individual rights will protect them against all authorities, including the indigenous one. In this spirit, the establishment of collective rights for indigenous peoples seems trouble-free.

\section{PARAMOUNT IMPORTANCE}

'The concept of indigenous peoples' collective rights is of paramount importance. It is the establishment of rights of peoples as groups, and not merely the recognition of individual rights, which is one of the most important purposes of this Declaration'.

\section{Existing provisions}

'Collective rights' does not constitute a new area for international law. The existing norms protect various aspects of groups. For example, art. 1 and 2 of the Convention on the Prevention and Punishment of the Crime of Genocide enumerates those acts which constitute genocide 'when intended to destroy, in whole or in part a national, ethnical, racial and religious group'.
Moreover, art. 1(4) of the Convention on the Elimination of All Forms of Racial Discrimination rejects the term racial discrimination for special measures that are adopted for the sole purpose of securing adequate advancement of certain ethnic groups. Also, the UNESCO Declaration on Race and Racial Prejudice establishes the responsibility of the state to protect human rights and fundamental freedoms on an equal footing for individuals and groups. The various instruments on minorities, such as art. 27 of the International Covenant on Civil and Political Rights (ICCPR) and the UN Declaration on Minorities also protect groups. More recently, various collective rights have been established per se, such as the right to self-determination, the right to development, the right to peace, the right to co-ownership of the common heritage of mankind, the right to a healthy environment and most relevant to our discussion - the right to preserve one's cultural identity. (For example, the UNESCO Declaration on Race and Racial Prejudice proclaims that 'all individuals and groups have the right to be different'.)

\section{Potential conflict?}

Still, even though group rights complement individual rights, there are certain cases where there is a conflict between collective and individual rights. The question is: which one will prevail in cases of conflict? Liberals tried to find a way for the adjudication of all these rights by giving a narrow interpretation to collective rights and by regarding them, as much as possible, as individual rights collectively pursued - and whenever that was not possible to rank them far behind the individual rights. This line of thought is manifested in the establishment of minority rights in international law as individual rights under collective capacity, rather than collective rights (thus minority rights are recognised as individual rights that can be exercised in community with others'; see, e.g. the UN Declaration on Ethnic, National, Religious or Linguistic Minorities and art. 27 of the ICCPR).

It seems that establishing a general rule of hierarchy of rights would be counter-productive. Garet (op cit) argues that any framework of accommodation of individual and collective rights would violate the principle of non-derivation among the three elements of a human being, namely personhood, communality and sociality. William Pertney explicitly rejects any hierarchy between collective and individual rights, although his general interpretative principles to facilitate their co-existence imply a prevalence of individual rights: firstly, 'the particular collectivity must not be impaired in its capacity to continue either by the State or by claims on behalf of individuals'; and secondly, 'a particular collectivity must respect the maximum individual rights consonant with the preservation of the group' (W F Pertney, The Aboriginal Rights Provisions in the Constitution Act, Saskatoon: Native Law Centre, 1987, 52, as quoted in Darlene Johnston (Kymlicka (ed)) Johnston notes that:

... in light of the potential diversity of group claims, it might be premature to attempt to construct a generalised framework for their adjudication'.

If community is seen as a constituent of individual identity, then enhancing collective rights need not diminish individual rights. By recognising the importance of sub-national groups, international law seems to emphasise the circumstances of mutual reinforcement between groups. Gutmann adopts an 
integrationist approach and comments that it may be possible 'to find ways in which local communities and democracy can be vitalised without violating individual rights' (Amy Gutmann, 'Communitarian Critics of Liberalism', 14 (1985) Philosophy and Public Affairs, 308-330). Johnston argues that 'collective and individual interests are not ... inevitably antagonistic. The supposed antithesis seems to be based on a particular and intolerant conception of the nature of group rights.'

International law also seems to oppose a pre-determined hierarchy among rights. Conflicts between rights is a common phenomenon of the legal profession. Any conflicts between rights, principles and norms are generally solved on an ad hoc basis, after taking into account various considerations. In possible conflicts between a collective and an individual right, the same process would be used.

Kymlicka opposes this process and accepts interference in the minorities' cultures when the individual rights of the members of the groups are violated (Will Kymlicka, 'The Rights of Minority Cultures, Reply to Kukathas', 20 (1992) 1 Political Theory, 140-145, 144). However, this interference is not clearcut. He suggests many criteria that will determine the prevalence of the individual right, including:

the severity of discrimination within the community, the extent of division within the community, the existence of any treaty obligations, the nature of the proposed interference, and so forth. For example, there is a large difference between cocrcively imposing liberalism and offering various incentives for liberal reforms.'

Kymlicka favours a search for agreement on fundamental principles. In any case, the two cultures will have to find a modus vivendi. Hence, if a minority culture is non-liberal:

liberals inside the culture will seek to promote their liberal principles through reason or example, and liberals outside would lend their support to any efforts the community makes to liberalise their culture.'

\section{TOGETHERNESS IN DIFFERENCE}

The 1966 UNESCO Declaration of the Principles of International Cultural Co-operation declares that:

in their rich variety and diversity, and in the reciprocal influences they exert on one another, all cultures form part of the common heritage belonging to all mankind.'

According to the declaration, cultural co-operation is a right and a duty for all peoples and nations. All nations must respect the distinctive character of each culture, while promoting their enrichment in an atmosphere of friendship and peace. Cultural co-operation aims at the mutual benefit of all the nations practising it and should be exercised in a spirit of broad reciprocity. Both the Council of Europe Framework Convention on National Minorities and the Organisation for Security and Cooperation in Europe (OSCE) Copenhagen Document re-assert the spirit of tolerance and intercultural dialogue, mutual respect and understanding that should exist among the minorities and the majority. The idea of reciprocity among cultures is emphasised in the following comment of the UN Committee on Human Rights in relation to the protection of cultural rights:

'The protection of these rights is directed to ensure the survival and continued development of the cultural, religious and social identity of the minorities concerned, thus enriching the fabric of society as a whole.' (emphasis added)

International law adopts a multicultural policy in relation to the various groups and their cultures, namely a policy that leads to equality among the groups and equal treatment. Through the celebration of difference or diversity, international law has fostered a constructionalist approach to culture, namely a view of culture as a relational concept: there can be no act of identification that does not already entail an act of differentiation (M Schulte-Tenckhoff, 'The right of persons belonging to minorities to enjoy their own culture', working paper for the 1997 UN Working Group on Minorities). However, differentiation is not viewed as exclusion. All the groups understand themselves as participants in the same society, subject to interaction, exchange and inter-dependency. The interaction sometimes causes friction and conflicts that are resolved following institutions and procedures of discussion that all participants have accepted as legitimately binding. These groups are heterogeneous, and have a differentiated place in public life. Young calls this model 'the heterogeneous public' (Iris Marion Young, 'Together in Difference: Transforming the Logic of Group Political Conflict' in Will Kymlicka (ed), The Rights of Minority Cultures, Oxford: OUP, 1995, 155-178, 157).

International law seems to approve the connection between the various groups that Young calls 'togetherness in difference'. Although Young is primarily interested in social groups, her approach seems very relevant to cultural groups. Various groups are seen as:

overlapping, as constituted in relation to one another and thus, as shifting their attributes and needs in accordance with what relations are salient. In my view, this relational conception of difference as conceptual helps make more apparent both the necessity and possibility of political togetherness in difference.'

In her model, Young suggests a conception of difference that better recognises the heterogeneity and diffusion of groups - a more fluid and explicitly relational conception of difference:

'In this conception, difference does not mean otherness, or exclusive opposition, but rather specificity, variation, heterogeneity. Difference names relations of both similarity and dissimilarity that can be reduced neither to coextensive identity nor overlapping otherness. Different groups potentially share some attributes, experiences or goals. Their differences will be more or less salient depending on the groups compared and the purposes of the comparison. The characteristics that make one group specific and the borders that distinguish it from other groups are always undecidable.'

Young's approach recognises that multiculturalism within the state is valuable and that all cultures are important for the development of the individual and the society in general. Cultures are not only permitted, but even assigned to have an input in the cultural life of the state and, in turn, the state guarantees group-related rights and policies. Cultures are not seen as contrasting, but as overlapping; differences are seen as 'variations' and are not ignored, but celebrated. Young's model indicates that apart from the cultures that form concentric circles, there are other cultures involved in the forming and development of the individual in a parallel way. It is thus viable in a multinational society to have the same amount of loyalty to two ethnic groups or two cultural groups. 


\section{CRITICAL PLURALISM}

UNESCO, which includes 186 member states, is dedicated to the development of international intellectual co-operation. The recent UNESCO World Commission on Culture and Development report entitled 'Our Creative Diversity' (chap. II, p. 70) emphasises the importance of cultural pluralism and political democracy. The report states that:

the challenge today ... is to develop a setting that ensures that development is integrative and that there are best practice institutions built on genuine commitment to being inclusive'.

Multiculturalism can exist only in a pluralistic society, where an array of choices and opportunities would maintain a marketplace of goods, ideas, cultural and political options. In this context, individuals that are not hopelessly dependent on specific cultural attachments will be able to make their own choices. This framework can be found in a pluralistic society, that is, advocated by cosmopolitans (Michael McDonald, 'Should Communities Have Rights? Reflections on Liberal Individualism' in 4 (1991) 2 Canadian Journal of Law and Jurisprudence, 217-237, 224).

Pluralism is viewed by many states as the main challenge to the state's sovereignty. (Michael Walzer, "Pluralism: A Political Perspective" in Will Kymlicka (ed)). The two concepts (pluralism and state sovereignty) are perceived as opposing and challenging. In the post-national state, these perceptions are inconsistent with reality. In fact, the recent events in former Yugoslavia indicate that pluralism may be the only way of maintaining a state's sovereignty. If the state denies its multicultural character, its citizens will inevitably feel dissatisfied and oppressed. As seen in the context of Eastern Europe and the former Soviet Union, oppressed groups are likely to revolt and try to undermine the state's sovereignty. In contrast, if pluralism and sovereignty are viewed as supplementing principles of this new order, collective rights will be recognised in the cultural groups of the state (pluralism) and the state can maintain its role as a decision maker, the manager of the various activities (sovereignty).

Adeno Addis makes the distinction between two forms of pluralism: paternalistic pluralism and critical pluralism. In paternalistic pluralism, minorities are viewed as the 'others' and their rights are protected as a means to 'save' them from the majority. In this model, the minorities themselves do not engage in a dialogue about their rights, because they are seen as unable to do so. It is the enlightened majority that decides how to 'save' them. Evident examples of this policy have been the policies of many governments towards indigenous peoples (Adeno Addis, 'Individualism, Communitarianism and the Rights of Ethnic Minorities', in 67 (1992) Notre Dame Law Review, 615-676, 620).

Unlike paternalistic pluralism, critical pluralism views minorities as partners in the creation or recreation of the society. The state actively engages in a dialogue with minorities in order to find the best way and resources to make minority cultures flourish. Moreover, the state creates institutions that enable the rest of the population to open itself up to all groups, by accepting them all as dialogue partners. Critical pluralism also believes in multiplicity: groups are seen as 'contingent rather than essential' and their very meaning can be moulded and reshaped through dialogue.

The idea of critical pluralism is realised through the various provisions on participation of minority groups in the decision- making process of the society they live in. The UN Declaration on Minorities proclaims that members of minorities have the right to participate effectively in decisions at the national and, where appropriate, regional level. In particular, the ILO Convention (169) concerning indigenous and tribal peoples in independent countries adopts a broad concept of participation in relation to indigenous peoples: states should not only consult indigenous peoples on matters which affect them directly; the consultations must be undertaken with the objective of achieving agreement or consent to the proposed measures.

In the dialogue process, groups are conceived as equal partners rather than negotiators or imitators of the dominant groups. The critically pluralist society does not transcend group differences; cultures are not surpassed but acknowledged and celebrated. Institutional dialogue is very important, because it leads to the re-evaluation Kymlicka argues for; groups are involved in mutual corrective engagements. Groups are reconceptualised and re-cast and their differences are adjusted and reconstituted in a process of constant and genuine dialogue. Through dialogue, groups are challenged to accommodate in their own world the objective reality of the other. They interact, exchange ideas and benefit from the cultures of all the groups rather than just from their own culture exclusively. As Falk notes (in Richard Falk, 'Cultural Foundations for the International Protection of Human Rights', A A An-Na'im (ed), Human Rights in Cross-Cultural Perspectives, A Quest for Consensus, Philadelphia: University of Pennsylvania Press, 1992, 43-64, 48):

'One role of the robust society is to overcome both normative and cultural blindness to human suffering. The raising of awareness requires deliberate efforts to counterpart the vulnerability of previously excluded groups; lessening vulnerability in turn depends on developing decentralised participatory democracy. ... Democratisation is both a vital precondition and a crucial ingredient of human rights protection.

\section{CONCLUSIONS}

The concepts of concentric loyalties, togetherness in difference and critical pluralism appear to be supported by the existing norms of international law. These concepts form the basis for the equal co-existence of collective rights with individual rights and combine the essence of liberalism with collective rights. If indigenous communities are accepted and recognised as bearers of rights and duties, there is a greater chance to develop a coherent set of doctrines to accommodate their real problems and concerns. The inclusion of a wide range of collective rights in the United Nations Declaration on the Rights of Indigenous Peoples will render affirmative action for these communities easier, and indigenous nations that have suffered discrimination for so long will eventually be compensated.

\section{Alexandra Xanthaki \\ Department of Law, Keele University}

This article is based on a paper presented in an earlier version at the World Congress on Philosophy of Law and Social Philosophy held at Pace University, New York, from 24 to 30 June 1999. The author is grateful to Professor P Thornberry, C Stefanou and R W Race for their comments. 